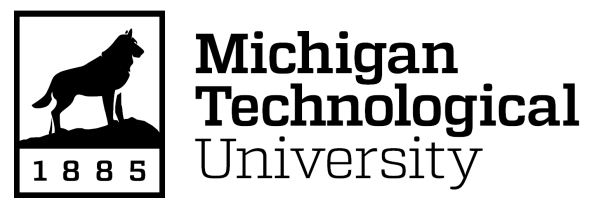

Michigan Technological University Digital Commons @ Michigan Tech

\title{
AN INVESTIGATION OF PROBLEM-BASED LEARNING ON THE ADVANCED PLACEMENT EXAM SCORES AND INTEREST OF AP BIOLOGY STUDENTS
}

Tia Hohler

Michigan Technological University, trhohler@mtu.edu

Copyright 2020 Tia Hohler

Recommended Citation

Hohler, Tia, "AN INVESTIGATION OF PROBLEM-BASED LEARNING ON THE ADVANCED PLACEMENT EXAM SCORES AND INTEREST OF AP BIOLOGY STUDENTS", Open Access Master's Report, Michigan Technological University, 2020.

https://doi.org/10.37099/mtu.dc.etdr/1100

Follow this and additional works at: https://digitalcommons.mtu.edu/etdr

Part of the Biology Commons, Curriculum and Instruction Commons, Educational Methods Commons, Science and Mathematics Education Commons, Secondary Education Commons, and the Secondary Education and Teaching Commons 


\title{
AN INVESTIGATION OF PROBLEM-BASED LEARNING ON THE ADVANCED PLACEMENT EXAM SCORES AND INTEREST OF AP BIOLOGY STUDENTS
}

\author{
By \\ Tia Hohler

\begin{abstract}
A REPORT
Submitted in partial fulfillment of the requirements for the degree of

MASTER OF SCIENCE
\end{abstract}

In Applied Science Education

MICHIGAN TECHNOLOGICAL UNIVERSITY

2020

Copyright 2020 Tia R. Hohler 
This report has been approved in partial fulfillment of the requirements for the Degree of MASTER OF SCIENCE in Applied Science Education.

Department of Cognitive and Learning Sciences

\author{
Report Co-Advisor: $\quad$ Amanda Gonczi \\ Report Co-Advisor: $\quad$ Shari Stockero \\ Committee Member: $\quad$ Tony Matthys \\ Department Chair: $\quad$ Kelly Steelman
}




\section{Table of Contents}

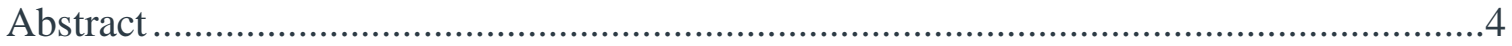

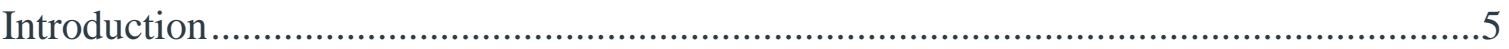

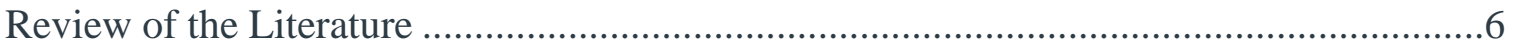

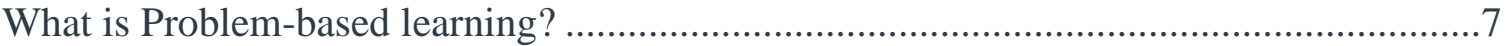

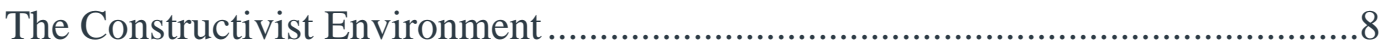

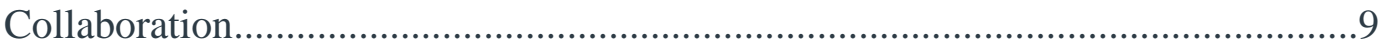

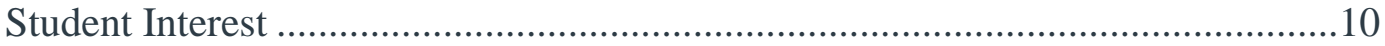

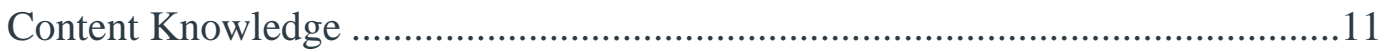

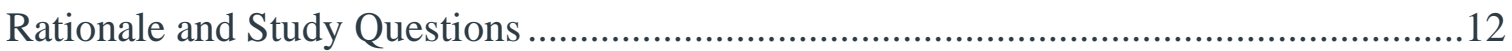

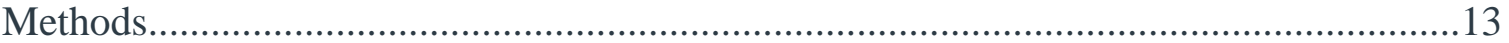

Research Approach and Ethics .................................................................. 13

Study Participants and Context .........................................................................13

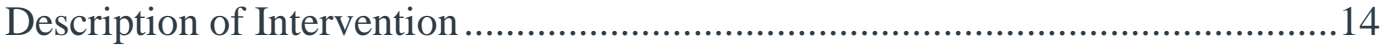

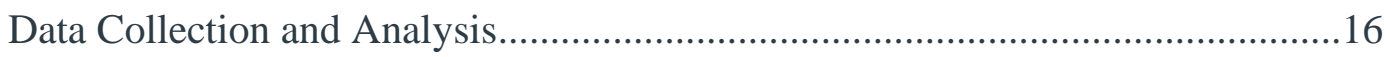

The National AP Biology Exam ............................................................16

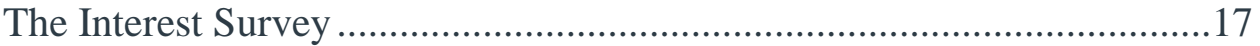

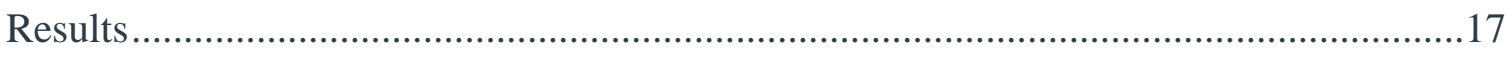

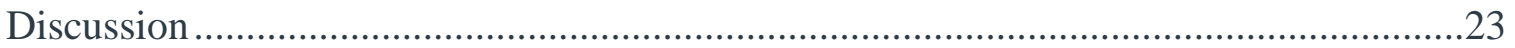

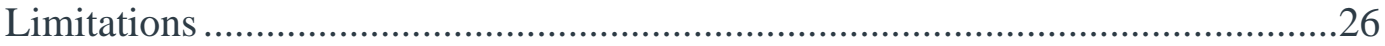

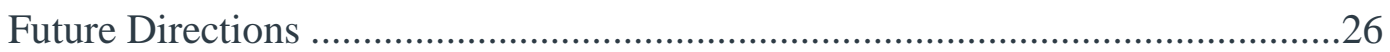

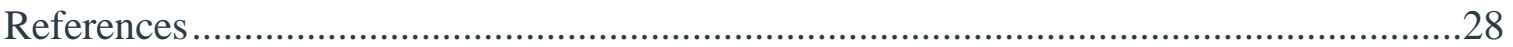

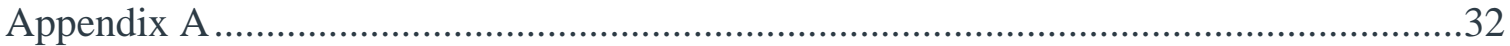




\begin{abstract}
This study reports the effectiveness of problem-based learning (PBL) on the interest and Advanced Placement (AP) Biology exam scores of high school students. The experimental group was exposed to a constructivist PBL environment using an overarching unit problem, inquiry style lab investigations and white board discussions while the comparison group received direct instruction in the same curriculum. AP Biology exam scores were collected for two years with direct instruction and two years with PBL instruction. An interest survey was given to a subset of the experimental group and included students enrolled in the course during the 2019-2020 school year. Analysis of the data revealed no significant difference between the AP exam scores of the experimental and comparison groups indicating that PBL did not affect the experimental group negatively or positively. While students reported that lab investigations were interesting, the overarching unit problem and white board discussions did little to increase their interest and motivation in class.
\end{abstract}




\section{Introduction}

Thirteen years ago, anonymous donors from the Kalamazoo area pooled money together to deliver a vision of free college for Kalamazoo Public School students, called the Kalamazoo Promise. While the Kalamazoo Promise gives college access to students who otherwise would not go to college, it does not guarantee success in college. The school where I work, Kalamazoo Central High School, created a mission statement and school improvement plan to promote a college-going culture in the community as well as to encourage habits that promote future success in college. These habits include setting goals, asking for teacher help and test taking skills. One way the school improvement plan is being realized is by expanding our AP course offerings and encouraging students to enroll in AP classes. Chajewski, Mattern, and Shaw (2011) found that students who took at least one AP exam enrolled in a four-year post-secondary institution at a higher rate than the national average, suggesting that there is potential that AP coursework can increase college participation and enhance college readiness. Passing an AP exam is an indicator that a student can be successful with college level rigor and may be more likely to do well in college compared to students that do not take AP classes. My school has articulated goals for students to work hard and increase their scores on the AP exam since there is a strong correlation between receiving a qualifying score ( 3 or above) on an AP exam and being successful in college (College Board, 2005).

One of the College Board's specific mission statements emphasizes the need for equitable access to AP courses and that AP classes should reflect the diversity of the student population in the school. Unfortunately, low-income and minority students in urban schools like the school I work in generally have access to fewer AP programs than 
students in more affluent schools and communities (Hallett \& Venegas 2011). In my own department, AP enrollment is low.

I am motivated to research how to improve students' performance on the national AP Biology exam to further the district's hope to promote a college ready population of students. I also want to study how to increase the interest of students in the AP Biology course content. Problem-based learning, an instructional approach, has increased student engagement, interest and learning in many studies, and may be an instructional approach that could improve student achievement in AP Biology (Hmelo-Silver, 2004; Hmelo, 1998; Schmidt, Rotgans \& Yew, 2011). I plan to use this instructional approach in my AP Biology class.

Interest in the curriculum is an important variable (Fredricks, Blumenfeld \& Paris, 2004). Greater interest could translate to more student effort trying to understand more difficult topics in AP Biology. Greater effort can in turn lead to greater achievement Therefore, I will investigate whether the AP Biology curriculum, implemented using a problem-based learning approach, can improve student achievement on the annual AP Biology exam and whether students report interest in components of the instructional approach.

\section{Review of the Literature}

Hallett and Venegas (2011) determined that while students took AP courses when given the opportunity, many students reported a low-quality AP experience in that the content was not immersive or interesting. Furthermore, the students' scores on their AP exams were low compared to their actual class grades. This indicates the students were ill-prepared for the AP exam. While the question of whether AP coursework contributes 
positively to college readiness and success is not in dispute, the quality of the content delivery and the role of the teacher in those classrooms should be scrutinized (Hallett \& Venegas, 2011). Based on Hallett and Venegas' (2011) findings, it becomes apparent that there is a need to increase the quality of the teaching without sacrificing rigor in AP courses. Students reported that teachers did not help students make connections with the material or make class motivating enough by providing engaging instruction. How can instruction in AP classes be improved? Successful science instruction methods in non-AP courses may offer promise, especially problem-based learning.

\section{What is Problem-Based Learning?}

Problem-based learning (PBL) is a form of experiential learning with constructivist roots (Schmidt, Rotgans \& Yew, 2011). This teaching method revolves around a problem that is used as an anchor for learning. Students are encouraged to collaborate and there are limited lectures with the instructional focus being more on student-directed learning. During PBL, the instructor serves as a guide during the lessons and most if not all the laboratory activities are inquiry based. While the role of the teacher is primarily a guide, it is important to understand that there is place for direct instruction during a PBL lesson. There is a place for scaffolding learning with lectures, especially if students are struggling with a problem due to a knowledge deficiency that they are unable to remedy on their own. (Hmelo-Silver, 2004).

There are many ways to implement a successful, collaborative environment using PBL. PBL is expansive and many strategies support PBL including project-based learning, anchored instruction, and case-based instruction (Hmelo-Silver, 2004). Discussing problems at the beginning of lessons activates prior knowledge and helps 
students process new information. A good problem that serves as the anchor or the hook of a lesson should be open-ended. It should also promote flexible thinking and be complex enough to have multiple ways of understanding it. These pedagogical strategies foster a classroom that is student-centered, self-reflective, and collaborative. In fact, some of the key features of a constructivist environment like PBL include an emphasis on problem-solving, collaboration, inquiry. Some major outcomes of PBL curriculum include increased student interest, increased depth of content knowledge, and increased retention of that knowledge (Heijne-Penninga, 2013; Hmelo-Silver, 2004). This review will discuss the two major features of PBL, constructivism and collaboration. My research focuses primarily on student interest and AP exam test scores which are tied to content knowledge; therefore this review will also discuss student interest and content knowledge as it relates to PBL.

\section{The Constructivist Environment}

The constructivist approach to learning is not a new one. Much research has been done on this pedagogy and its benefits to learners. The students' unique perspectives and questions are used in a collaborative, constructivist classroom environment (Kim, 2005). There is an emphasis on big ideas and the teachers are very interactive with the students. Students are often placed in groups with specific jobs and assessment occurs throughout the process. Nayak (2007) further emphasizes that this classroom environment is student-centered, with the learning process being very active. Qarareh (2016) states that in addition to using a problem to engage students, inquiry-based lab investigations are often used to help students explore their topic and gather more information. This is a stark contrast to traditional classroom models where the teacher is 
the primary source of information. In a traditional, teacher-centered classroom, the instructor often unloads information on students in a lecture format with little attention paid to skill development. Students learn a collection of facts disconnected from each other and memorization is emphasized instead of meaning construction (Taraban et. al, 2007). In a study by Kim (2005), it was determined that students being instructed in a constructivist classroom environment performed significantly better than their peers in the traditional learning environment on an academic test. Sagge (2016) confirmed these results. Nayak (2007) and Kim (2005) both advocate the student-centered approach to laboratories and a collaborative mindset because of the measured significant growth in classrooms using those methods compared to traditional, independent learning. In a study by Gormally et al. (2009), students in inquiry-based labs were measured against students in traditional lab settings. The students in the inquiry lab sections performed significantly better on a science literacy assessment and higher on a science skills assessment than the traditional group.

\section{Collaboration}

Based on the literature, collaboration is highly recommended during laboratories and discussions because it improves the student experiences in a constructivist environment such as PBL (Gormally et al. 2009; Kim, 2005; Nayak, 2007; Qarareh, 2016; Sagge, 2016). Furthermore, collaboration is one of the most important hallmarks of a successful PBL program (Schmidt, Rotgans \& Yew 2011). In a study by Gallardo et al. (2016), students' learning habits and time allocation were measured using a PBL approach to learning compared to a traditional instructional method. Students in the PBL curriculum spent twice as much time working in groups than the traditional method. 
Students reported a positive experience with collaboration during PBL lessons online according to a study by Sulaiman et. al (2004) and increased their performance on lesson tasks.

One way to promote the collaborative components of problem solving is using a class whiteboard. Students use the white board to work in collaborative groups to learn what they need to know to solve the problem. This method helps the teacher identify knowledge gaps and to track progress (Hmelo-Silver, 2004). The whiteboard can also serve as a focal point for discussion and collaborative construction of knowledge.

\section{Student Interest}

One reason why PBL is such a powerful instruction strategy is because of its potential to motivate students to learn through increasing their interest. Since my research is focused on student interest in biology being affected by aspects of PBL, it is important to discuss what has been found to increase student interest. Situational interest is spontaneous, related to a learning task and provoked by an environmental stimulus (Hidi \& Renninger, 2006). Situational interest is important in catching and keeping the students' attention, especially if the problem is novel. Greater situational interest can improve memory, comprehension, and cognitive engagement (Palmer, 2009). This was researched by Schmidt, Rotgans and Yew (2011), when student situational interest was measured throughout a set of lessons. Two groups, one instructed with direct instruction and the other with PBL were compared. Over time, PBL students were found to have maintained more situational interest than the direct- instruction group. While participating in PBL lessons, student interest increased according to a study by Sulaimon et. al (2004). 
The instructor plays an important role in creating an environment that triggers and maintains student interest during PBL. The teacher can present an anchor problem that is novel or sensational. The instructor can let students create their own groupings to facilitate collaboration during discussions and experiments (Palmer, 2009; Schraw, Flowerday and Lehman, 2001; Schmidt, Rotgans and Yew, 2011). In a study by Palmer (2009), students in a high school science classroom were given a short, inquiry style lesson and situational interest was measured throughout the lesson components. While the study found that situational interest fluctuated throughout the lesson, the highest amounts of interest were generated when the teacher demonstrated a novel idea. The second highest amount of interest occurred when the students could experiment with the content. The lowest interest was generated while the students copied notes, a directinstruction strategy.

\section{Content Knowledge}

In addition to promoting student interest, PBL has the ability to promote flexible, deep knowledge of concepts that goes beyond memorizing disconnected facts. My research is concerned with improving AP exam scores which are a measure of content knowledge; therefore, it is vital that content knowledge as an outcome of PBL is discussed. As a result of PBL instruction, students have been found to have an increased ability to formulate problem solving scenarios and scientific explanations (Hmelo-Silver, 2004). In a study by Hmelo (1998), PBL and traditional students were compared over their first year of medical school as they developed explanations for causes of diseases. They were compared in terms of accuracy, coherence and use of scientific concepts. In initial testing before the lessons, both groups of students did not differ in their 
explanations. After three and then seven months, the study concluded that PBL students were more likely to use science concepts and construct more accurate responses than the traditional group. In a study by Casla \& Zubiaga (2010), students were monitored over four years of a PBL curriculum and consistently had higher test scores than their peers in traditional learning groups. Not only do students score higher on tests after engaging in PBL, they have more confidence in their understanding. In a study by Sulaimon et. al (2004), students perceived themselves more knowledgeable about their subject when instructed in PBL versus students using traditional curricula.

Content retention is also significantly improved by PBL. In a study by HeijnePenninga et. al (2013), students in two different PBL curricula scored better on a knowledge exam and demonstrated significantly better long-term knowledge retention than students in a traditional curriculum. Similarly, in a study by Dods (1997), students in a PBL curriculum performed better on an assessment measuring content retention, than their peers in a traditional curriculum.

\section{Rationale and Study Questions}

I did this study because, to my knowledge, research on problem-based learning in AP classrooms is nonexistent. There have been very few studies on student interest in AP science classes. Science is sometimes deemed boring and too complex by teens so there is a real problem of low interest in science classes (Palmer, 2009). AP classes are complex, college level classes. Added to that complexity are high school aged students that often have low academic interest which can impede their learning. In my study, I examined 
whether PBL could increase student interest and achievement in an AP Biology course. My research questions were:

1. What components of problem-based learning did students in an AP Biology classroom find most and least interesting and why?

2. What is the effect of problem-based learning on students' National AP Biology scores?

\section{Methods}

\section{Research Approach and Ethics}

The research approach was action research with a quasi-experimental design. This design was chosen since this study took place in my own classroom with a comparison group for the purposes of refining my own teaching practice. This type of research also required some reflection upon my current practices (Thomas, 2017). Students and parents signed an IRB consent form indicating whether they gave their permission to have their students' scores and survey answers used in the study. Student data are reported in aggregate and pseudonyms are used to protect identity. There were no known negative impacts from the intervention used in the study. Students or their parents who did not wish to have their data used were excluded from the study.

\section{Study Participants and Context}

The study was conducted at an urban, public high school. The study population consisted of 85 students who were in grades 11 and 12 while they were enrolled in the AP Biology course during one of four academic years: 2016-2017; 2017-2018; 20182019 and 2019-2020. The first two years were the non-PBL group and the second two years were the PBL group (Table 1). 
Table 1 Experimental Setup

\begin{tabular}{|c|c|c|c|}
\hline \multicolumn{2}{|c|}{ Comparison Group (no PBL) } & \multicolumn{2}{|c|}{ Experimental Group (PBL instruction) } \\
\hline Year & \# students & Year & \# students \\
\hline $2016-2017$ & 27 & $2018-2019$ & 25 \\
\hline $2017-2018$ & 15 & $2019-2020$ & 19 \\
\hline
\end{tabular}

\section{Description of Intervention}

The curriculum and topics in the AP Biology course are standardized through the College Board (College Board, 2015). The comparison group (students in the course during 2016-2017 and 2017-2018) were taught in a traditional lecture style method using Powerpoint with worksheet type assignments and structured laboratory assignments. Lessons were teacher directed and non-collaborative with the exception of required AP Biology labs. The experimental group was taught using a problem-based teaching method with the same worksheets and laboratory assignments. The content was embedded within a real-world problem that was posed to students at the beginning of the unit. The laboratory assignments were inquiry style (see Table 2 for an example). All formative and summative assessments given to the comparative and treatment groups were the same. 
Table 2 Comparison of Classroom Environments

\begin{tabular}{|c|c|c|}
\hline Unit Component & Comparison Group (Direct instruction) & $\begin{array}{l}\text { Treatment Group (Problem-based } \\
\text { learning) }\end{array}$ \\
\hline Introduction to Unit & $\begin{array}{l}\text { Nothing formal: Example: Today we are } \\
\text { going to begin learning about signal } \\
\text { transduction and cell transport. }\end{array}$ & $\begin{array}{l}\text { Introduce Problem: Example: How does } \\
\text { Magic Berry work? How does Gymena Tea } \\
\text { work? } \\
\text { Hook Experience: Example: Students try the } \\
\text { Magic Berry and the Gymena tea and eat } \\
\text { various types of candies of different } \\
\text { flavors. Students write down their initial } \\
\text { sensations before and then after the } \\
\text { experience. }\end{array}$ \\
\hline $\begin{array}{l}\text { Lecture/Discussion } \\
\text { Component }\end{array}$ & $\begin{array}{l}\text { Sharing ideas: raise their hands and ask } \\
\text { questions, teacher or student gives answers. } \\
\text { Lecture including vocabulary words and } \\
\text { main topics, students are given a copy of the } \\
\text { lecture notes. Students ask questions as } \\
\text { needed. Teacher goes through Powerpoint } \\
\text { slides and talks most of the time. }\end{array}$ & $\begin{array}{l}\text { Sharing ideas: After the initial experience, } \\
\text { students are invited to put questions or } \\
\text { wonderings on a whiteboard on the side of } \\
\text { the classroom. The whiteboard is added to } \\
\text { by various students and the teacher } \\
\text { throughout the unit and students construct } \\
\text { meaning. Teacher goes through Powerpoint } \\
\text { slides as students add questions and facts to } \\
\text { the discussion whiteboard. Students relate all } \\
\text { information to the initial hook experience. } \\
\text { Students do most of the talking and teacher } \\
\text { fills in knowledge gaps using the Powerpoint. }\end{array}$ \\
\hline Laboratory Experience & $\begin{array}{l}\text { Structured inquiry lab- Students are given the } \\
\text { research question and methods. } \\
\text { *Students are given a standard procedure to } \\
\text { follow } \\
\text { *Students gather their own data and put data } \\
\text { and calculations into a table. } \\
\text { *Students are given the methods to gather the } \\
\text { data and create a lab report. }\end{array}$ & $\begin{array}{l}\text { Guided inquiry lab- } \\
\text { Example: How do the solutions inside and } \\
\text { outside a cell affect the way water is } \\
\text { transported? } \\
\text { *Students are given materials and create their } \\
\text { own methods and lab report. } \\
\text { *Students collect the data and use the data to } \\
\text { answer the question while making a graph or } \\
\text { visual to communicate their results. }\end{array}$ \\
\hline Summary & $\begin{array}{l}\text { Students review all the vocabulary and main } \\
\text { ideas to prepare for the assessment. }\end{array}$ & $\begin{array}{l}\text { At the end of the unit before the assessment, } \\
\text { students discuss the relevance of what they } \\
\text { learned to the initial question along with any } \\
\text { other questions that came up during their } \\
\text { learning process. Students attempt to explain } \\
\text { the answer to the initial experience or } \\
\text { problem. Teacher fills in gaps as needed. }\end{array}$ \\
\hline Assessment & $\begin{array}{l}\text { Multiple choice and free response assessment } \\
\text { are given. }\end{array}$ & $\begin{array}{l}\text { Multiple choice and free response assessment } \\
\text { are given. }\end{array}$ \\
\hline Homework & $\begin{array}{l}\text { Homework is scheduled daily and is a } \\
\text { worksheet type assignment with vocabulary } \\
\text { to practice and diagrams to label. }\end{array}$ & $\begin{array}{l}\text { Homework is scheduled daily and is a } \\
\text { worksheet type assignment with vocabulary } \\
\text { to practice and diagrams to label. }\end{array}$ \\
\hline
\end{tabular}

During the experimental years, the problem was introduced at the start of each

unit. Various methods were used to introduce the problem including video clips, text, and

lab experiments. The problem was written on a whiteboard divided into three sections

labelled "Ideas", "Questions", and "What We Figured Out." Prior to a lecture and

discussion component, students were encouraged to offer ideas for exploration regarding

the problem. If students had questions at the beginning of the lecture, then they were 
encouraged to write them on the whiteboard and/or share them with the class. Throughout the unit, the whiteboard was updated with the knowledge the students developed through unit activities, with the students eventually developing one possible solution to the problem. Lecture was minimal in the PBL years and was only given to supplement and address gaps in students' knowledge.

\section{Data Collection and Analysis}

This study incorporated qualitative and quantitative data including students' National AP Biology exam scores and an interest survey. These data sources are described below as well as methods of analysis.

\section{The National AP Biology Exam}

The AP Biology exam is written by the College Board, and is given in May of every year. AP Biology scores for all students between 2016-2019 were included in analysis. AP exams are scored by trained scorers selected by the College Board and are given scores from 1 to 5, with students receiving college credit for scores of 3 and above. The scores from the students in both the comparison and experimental groups were compared using an unpaired t-test that used an alpha of .05 as a cut off for significance. This test was used to determine if there was significant difference in the average score of the comparison and treatment groups to determine if the intervention had any effect on the scores from the College Board National AP Biology Exam.

The AP Biology scores for each group were analyzed in Google sheets. The comparison group scores on the AP Biology exam were tabulated in sheets and the mean, standard deviation and confidence level were calculated. The same was done for the experimental group. Both groups' scores were graphed. Errors bars were used 
representing standard error. If the bars overlap, then the data may not be significant. If the error bars do not overlap, the data may be significant and more analysis using an unpaired t-test was used to confirm or reject this hypothesis. If the t-test p-value was determined to be less than .05 , then the difference in the scores of the two groups was considered significant. For each year of study, students' mean scores were tabulated and individual score distributions were examined.

\section{The Interest Survey}

The interest survey consisted of six, open-ended questions designed to measure student's overall interest in the different aspects of the PBL method. (Appendix A). This survey was given to the 2019-2020 class $(n=19)$ at the end of the course using an anonymous Google form via Google classroom. Only 7 out of the 19 students (37\%) returned surveys.

Student responses on open-ended questions were coded using thematic data analysis (Braun \& Clarke, 2006). The responses were downloaded in a Google sheet for analysis and students were assigned numbers for de-identification purposes Main themes were identified, and sub- codes identified as needed with the open-ended responses. This type of coding was used to determine if the students perceived themselves as interested in different aspects of the science lessons.

\section{Results}

An analysis of the data demonstrated that there were no significant differences between the comparison and the experimental group AP exam scores. The mean test score for the comparison group was $2.90(\mathrm{SD}=1.16)$ while the experimental group was 
$2.72(\mathrm{SD}=.91)$. The results of the unpaired $\mathrm{t}$-test returned a $p$ value of .42 indicating no significant difference between the scores.

Because last school year of the study (2019-2020) was disrupted by COVID-19, further analysis was conducted to disaggregate and compare data in each of the four years. The AP score mean and percentage of students receiving college credit (3 or above) was calculated for each year of the study. Results are summarized in Table 3. The data indicates a lower AP score mean and less students receiving college credit during the 2019-2020 school year compared with the three previous years.

Table 3 Standard deviations, mean and percentage of students receiving college credit for all the study years

\begin{tabular}{|c|c|c|c|}
\hline School Year & Standard Deviation & Mean & $\begin{array}{c}\text { Percentage of } \\
\text { students receive } \\
3 \text { or above }\end{array}$ \\
\hline $2016-2017$ & 1.22 & 2.89 & $59 \%$ \\
\hline $2017-2018$ & 1.10 & 2.93 & $60 \%$ \\
\hline $2018-2019$ & .75 & 3.04 & $72 \%$ \\
\hline $2019-2020$ & .95 & 2.32 & $37 \%$ \\
\hline
\end{tabular}

For each of the school years in the study, the distribution of all the AP scores was compared. The data indicates that there was a larger distribution of scores in the direct instruction years (comparison group) than the PBL years (experimental group). The pandemic year (2019-2020) had the lowest scores than the other years with distribution skewed towards the lower end. Results are summarized in Figure 1. 


\section{Figure 1}

\section{AP Exam Score Distribution}

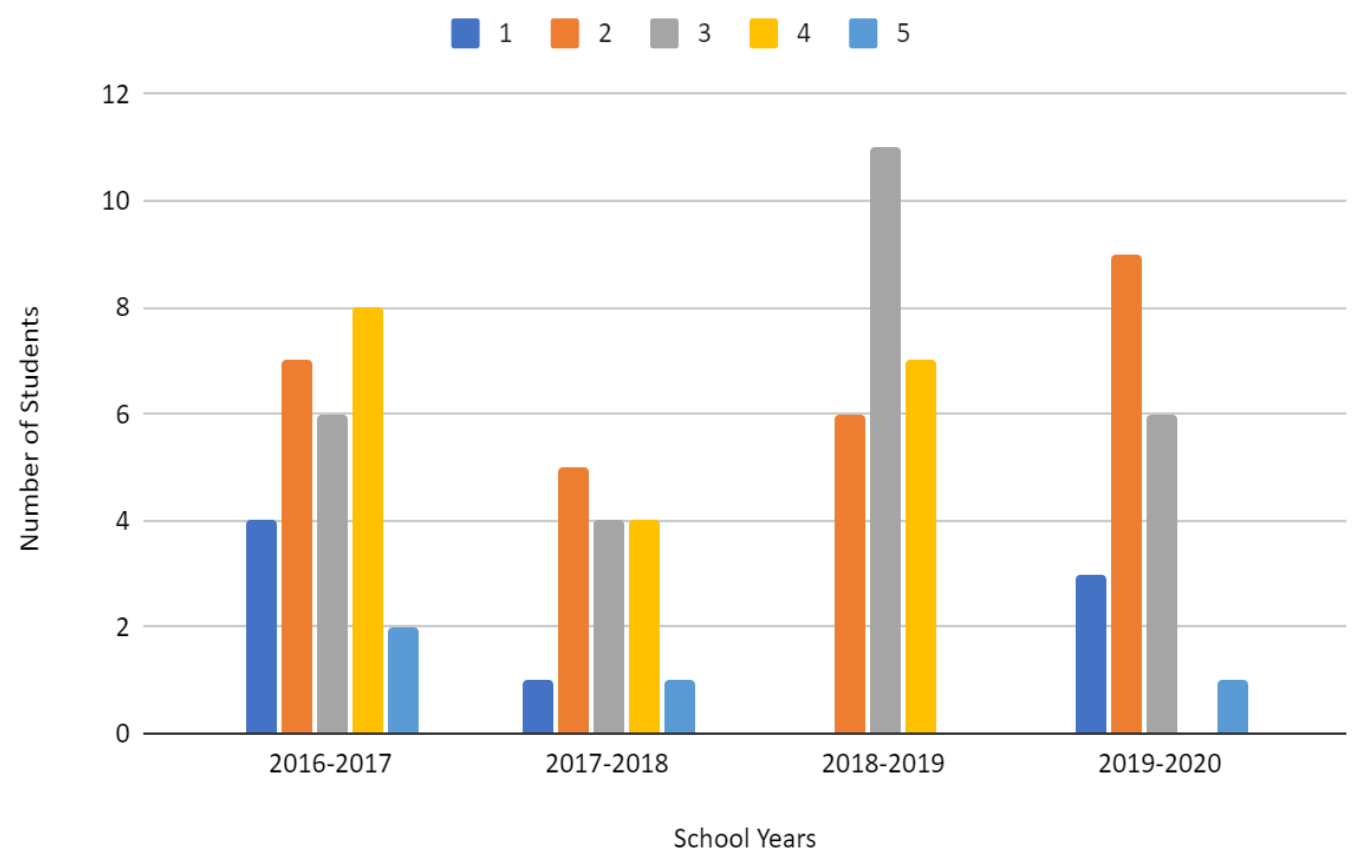

All the students surveyed indicated that they preferred the lab investigations over the overarching unit problem and the whiteboard discussions. Students were asked why the aspect of the unit they selected, in this case the lab, was most interesting. The majority of the students responded that the labs were hands on and interactive. Others remarked that the labs were interesting, got their attention and made things easier to learn. Table 4 summarizes the results of this question. 
Table 4 Why was that aspect of the unit [the lab] the most interesting to you? Please explain in detail.

\begin{tabular}{|c|c|c|}
\hline Code & $\begin{array}{l}\text { Frequency of } \\
\text { Responses }\end{array}$ & Exemplar Quote \\
\hline Hands-on/interactive & 5 & $\begin{array}{l}\text { "The hands-on experience showed } \\
\text { us what we were talking about in } \\
\text { our discussions." (student } 1 \text { ) }\end{array}$ \\
\hline Love/Like Labs, Fun, interesting & 2 & $\begin{array}{l}\text { "I loved lab experiments because } \\
\text { they were Hands-On and really fun } \\
\text { and quite a lot of attention which } \\
\text { forced learning." (student } 2 \text { ) }\end{array}$ \\
\hline Learn better/Easier to understand & 3 & $\begin{array}{l}\text { "Hands on and made it easier to } \\
\text { understand things." (student 3) }\end{array}$ \\
\hline Got Attention & 2 & $\begin{array}{l}\text { "These lab investigations were the } \\
\text { most interesting because it allowed } \\
\text { us to really dig into the depths of } \\
\text { the topic and truly understand what } \\
\text { we were learning because we got } \\
\text { to experience and watch it } \\
\text { firsthand. It was more interactive } \\
\text { which meant I was able to give it } \\
\text { more attention and really get into } \\
\text { it." (student 4) }\end{array}$ \\
\hline Real-World & 1 & $\begin{array}{l}\text { "Used the problem in the real } \\
\text { world." (student 5) }\end{array}$ \\
\hline Like the particular topic & 1 & $\begin{array}{l}\text { "Heredity and genealogy. I loved } \\
\text { doing the Punnett squares and } \\
\text { figuring out the offspring. It was } \\
\text { very interesting to me." (student } 6 \text { ) }\end{array}$ \\
\hline
\end{tabular}

In terms of what students found the least interesting about the unit, all the students except one found the overarching unit problem the least interesting. One student found the discussions the least interesting. When asked why they found these aspects the least interesting, students remarked that the unit problem wasn't memorable and was an afterthought. Some of the students didn't connect to the problem or care enough about it to internalize it. Table 5 summarizes the students' statements. 
Table 5 Why was that aspect the least [unit problem or discussion] interesting to you?

Please explain in detail.

\begin{tabular}{|c|c|c|}
\hline Code & $\begin{array}{l}\text { Frequency of } \\
\text { Responses }\end{array}$ & Exemplar Quote \\
\hline $\begin{array}{l}\text { Not memorable, } \\
\text { afterthought, forgot }\end{array}$ & 2 & $\begin{array}{c}\text { "It was interesting but not that memorable and I } \\
\text { feel like within the larger unit it just became an } \\
\text { afterthought." (student 4) }\end{array}$ \\
\hline Hard to Understand & 2 & $\begin{array}{l}\text { "If it's like a long-worded question (LEQ) or } \\
\text { whatever, it's hard for me to like understand it } \\
\text { sometimes because like it's just a lot of words and } \\
\text { things to do and sometimes it's worded difficultly." } \\
\text { (student 6) }\end{array}$ \\
\hline $\begin{array}{l}\text { Hard to maintain } \\
\text { focus }\end{array}$ & 1 & $\begin{array}{l}\text { "These whiteboard discussions were the least } \\
\text { interesting to me because although it was a helpful } \\
\text { method of learning, most of the facts and questions } \\
\text { on the board were not mine, so this meant it was } \\
\text { harder to maintain focus and tune in for the } \\
\text { whole conversation. While looking at a problem, } \\
\text { and doing the labs, were both more enticing." } \\
\text { (student } 1 \text { ) }\end{array}$ \\
\hline Ideas not my own & 1 & $\begin{array}{l}\text { "These whiteboard discussions were the least } \\
\text { interesting to me because although it was a helpful } \\
\text { method of learning, most of the facts and } \\
\text { questions on the board were not mine, so this } \\
\text { meant it was harder to maintain focus and tune in } \\
\text { for the whole conversation. While looking at a } \\
\text { problem, and doing the labs, were both more } \\
\text { enticing." (student 1) }\end{array}$ \\
\hline $\begin{array}{l}\text { Didn't like the } \\
\text { topic }\end{array}$ & 1 & $\begin{array}{l}\text { "The aspect that was least interesting to me was the } \\
\text { chi squares. I guess it was because it was confusing } \\
\text { for me and I really never got it down." (student 2) }\end{array}$ \\
\hline $\begin{array}{l}\text { Didn't care about } \\
\text { the problem }\end{array}$ & 1 & $\begin{array}{l}\text { "Although it was cool to think about, I never cared } \\
\text { for the problem to think about it." (student 3) }\end{array}$ \\
\hline Liked everything & 1 & $\begin{array}{l}\text { “There isn't one I just had to make a selection." } \\
\text { (student 5) }\end{array}$ \\
\hline
\end{tabular}

The last survey question asked students whether an overarching unit problem (the anchor) affected their interest in the unit and to provide an explanation. While two of the students reacted very favorably to the unit problem in that it made them want to learn, two others did not feel their interest was affected at all. Most of the students were 
generally ambiguous about the problem indicating that some interest was there but not enough to make a difference. Table 6 summarizes these results.

Table 6 Did giving a problem at the start of each unit affect your interest in the course/unit? Please explain in detail.

\begin{tabular}{|c|c|c|c|}
\hline $\begin{array}{l}\text { Code 1: Did } \\
\text { problem } \\
\text { affect } \\
\text { interest (n) } \\
\end{array}$ & Code 2: Explanation & $\begin{array}{l}\text { Frequency of } \\
\text { Responses }\end{array}$ & Exemplar Quote \\
\hline \multirow[t]{2}{*}{ Yes $(n=4)$} & Attention Grabbing & 2 & $\begin{array}{l}\text { "Yes, giving a problem at the } \\
\text { beginning of each unit increased my } \\
\text { interest for the topic, because it } \\
\text { caught my attention, and made } \\
\text { sure I gave my attention throughout } \\
\text { the unit in order to learn more about } \\
\text { the problem. It gave me a reason to } \\
\text { keep on learning more about the } \\
\text { course/unit." (student } 6 \text { ) }\end{array}$ \\
\hline & $\begin{array}{l}\text { Reason to keep learning/made } \\
\text { me want to learn }\end{array}$ & 2 & $\begin{array}{c}\text { "yes, because it made me want to } \\
\text { learn the materials in the unit so I } \\
\text { could understand the problem." } \\
\text { (student } 2 \text { ) }\end{array}$ \\
\hline \multirow[t]{2}{*}{ No $(n=2)$} & Not memorable & 1 & $\begin{array}{l}\text { "It was a cool attention grabber, but } \\
\text { it wasn't that memorable overall." } \\
\text { (student } 4 \text { ) }\end{array}$ \\
\hline & Not interesting/didn't care & 1 & $\begin{array}{l}\text { "No, it did not affect my interest } \\
\text { even if it did, it was only a little. I } \\
\text { just did not care enough to think } \\
\text { about more than I could } \\
\text { comprehend." (student } 3 \text { ) }\end{array}$ \\
\hline \multirow[t]{3}{*}{$\begin{array}{l}\text { Ambiguous } \\
(\mathrm{n}=4)\end{array}$} & Made a connection with unit & 2 & $\begin{array}{c}\text { "Some yes/some no. The food } \\
\text { changing one was really good and } \\
\text { saw how it connected into the unit." } \\
\text { (student 5) }\end{array}$ \\
\hline & Interesting & 1 & $\begin{array}{l}\text { "It did affect my interest in the } \\
\text { course by if I thought that it } \\
\text { sounded interesting or if it sounded } \\
\text { very difficult. When the question } \\
\text { seemed very difficult, I was not } \\
\text { interested in the course." (student } 1 \text { ) }\end{array}$ \\
\hline & No explanation & 1 & N/A (student 7) \\
\hline
\end{tabular}




\section{Discussion}

During this study, I have reflected upon what the results mean to my own teaching practice. I have learned through my research about the identifying characteristics of a good PBL implementation and the many benefits of incorporating PBL into my curriculum. While my results from my study concluded no significant difference in the test scores between the comparison and experimental groups, there was much to be gained from this experience.

I did gain some insight into the student experiences and how the students perceived the instruction and what they enjoyed doing while working through the class. All the students surveyed preferred the lab investigations and I feel that I designed them properly using inquiry style methods with allowing significant collaboration between the students. One student remarked that the lab investigations were fun and really allowed them to dig deeper into the material (student 4). This information tells me to continue to include lab investigations as a part of my curriculum and even increase the amount of activities offered.

There were some aspects of the course that students did not like. Most students surveyed did not like the overarching unit problem for various reasons. Several students did not feel the problem was memorable even though it was attention grabbing at first. The students' interest seemed to wane throughout the unit as described by a couple students that said the problem piqued their interest but did not hold it, especially if the topic was difficult to understand.

I believe the reason the unit problem was not received more favorably was my shortcomings in my knowledge of how to properly implement PBL. For optimal learning, 
motivational strategies must be coupled with instructional strategies to encourage scientific thinking and maintain the level of interest throughout the lessons. This maintenance requires relevant tasks and/or personal involvement with the content (Hidi \& Renninger, 2006; Palmer, 2009). One of the goals of PBL is to intrinsically motivate students by creating learning moments related to a student's own interests (Hmelo-Silver, 2004). This relevance is one of the many factors that influence situational interest in a classroom along with student autonomy, choice, and complexity of the lesson problem (Palmer, 2009; Schraw, Flowerday and Lehman, 2001). Students chose to work on complex problems versus simple ones when the problem was relevant, and students reported that social interaction increased their interest in the lesson. It can be reasonably concluded that a relevant problem in the vein of PBL will promote student interest and possibly lead to increased learning outcomes.

I believe that I did not properly connect the unit problem with the tasks that I assigned during the lessons. I also did not continually refer to the problem in the context of the lessons and make it relevant often enough to promote and keep the interest of the students. It is important before adopting a PBL ideology in the classroom, that teachers are adequately instructed in these methods. Similarly, students can be instructed in the activities that would accompany such an environment (McPhail, 2016). With this in mind, I will need to improve my implementation of PBL in the future by returning to the unit question more often through the unit, paying specific attention to creating lab investigations that refer directly to the overarching unit question and creating a unit question that is relevant. 
When looking at the test scores on the AP Biology exam, there was no significant difference between the two groups of students' scores. The mean of the student groups was very similar. Based on this, I can conclude that the use of PBL did not either negatively or positively affect the experimental group. This is a contrast to the results from studies by Dods (1997), Casla \& Zubiaga (2010), and Heijne-Penninga et.al (2013), which found that content knowledge retention and test scores increased with the use of PBL. One possible reason for these results is that the experimental group did not connect the problem with the class material in a deep enough way as to increase their content knowledge above and beyond what they would have done using non-PBL instruction. The score distribution and mean varied from year to year. While the two school years from the comparison group had similar means, there was a small increase in the exam score mean for the first year I implemented PBL (Figure 1). After this, however, there was a sharp downturn the following year. Thus, the experimental group had both the highest and lowest means in the study. The mean for the group that took the exam during the pandemic was the lowest out of all the study years and had a score distribution skewed towards the lower scores. Less students received AP credit during the pandemic year. (Table 3) It is my feeling that the virtual learning that occurred prior to taking the exam and the format of the exam itself may have negated any progress the students might have gained while using the PBL curriculum that year. Standard deviations for the experimental groups were less than the comparison group indicating less spread in the scores (Table 3). 


\section{Limitations}

There were several limitations to this study. First, there were inconsistent testing procedures across the years. The most recent student group (2019-2020) had to take the AP test in a different format than all the other students from the previous years. While the AP test is normally given with a paper and pencil, the 2019-2020 test was given online due to the covid-19 epidemic. The exam was also shortened and included no multiple choice as had been done in previous years. Furthermore, the students from this year, were in virtual learning for the months of March and April leading up to the exam in May. Due to the constraints of virtual learning, PBL had to be suspended during that time in favor of a more traditional approach that fit better with online learning. During online learning, there was a sharp decrease in engagement as evidenced by less assignments being turned in and less participation in class.

Another limitation was the small sample size of surveys that I obtained. I only have survey data from the most recent group of students (2019-2020) and of that group, only seven students returned surveys. It would have been more helpful to have survey data from more students from that year and survey data from previous years to compare to. This data would have strengthened my study in that I would have more responses that would allow me to see more reasons why the students did or did not find interest in certain parts of the unit.

\section{Future Directions}

In the future, I would like to try to use PBL with another class in perhaps another discipline such as AP Environmental Science. I feel I need better training and research on implementing PBL before I do this, however. I would like to go to a conference or 
seminar and learn more about incorporating PBL in my own classroom. I think this would make me more confident in creating an anchor that weaves throughout the unit and creating student activities that support figuring out solutions to the problem. Using PBL in a K-12 environment comes with challenges. Teachers typically assess in very specific disciplines within their subjects and some problems do not directly translate to those areas (Symeonidis \& Schwarz, 2016). While PBL can be implemented in K-12 with careful planning, the full benefits of PBL are seen when the problem becomes multidisciplinary (Hmelo-Silver, 2004). I would like to incorporate PBL into a variety of disciplines in my school to make the learning truly immersive. Then I can repeat my experiment with a larger sample size. I think that is a long- term goal.

In the end, I feel that while implementing PBL is a challenge for not only the students but for the teachers as well, it has a place and real value in the K-12 curriculum. I think teachers and students will struggle to find their respective roles in while using PBL because it is something they are not used to. There were certainly bumps in the road that I experienced while doing this research much of which was my own shortcomings and lack of experience with PBL. Symeonidis \& Schwarz (2016) remark that enhancing true achievement in the classroom is the responsibility of both the teacher and the student: "Neither teachers nor students alone contribute to successful learning outcomes, but within the responsive relation occurs a transformation that is the work of both." (p. 42). 


\section{References}

Braun, V. and Clarke, V. (2006) Using thematic analysis in psychology. Qualitative Research in Psychology, 3 (2), 77-101. ISSN 1478-0887

Casla, A. and Zubiaga, I. (2010) Problem-based learning; Paternity Testing in a PBL Environment. Biochemistry and Molecular Biology Education, 38 (1), 37-42. https://iubmb.onlinelibrary.wiley.com/doi/epdf/10.1002/bmb.2036

Chajewski, M., Mattern, K. D., \& Shaw, E. J. (2011). Examining the role of Advanced Placement ${ }^{\circledR}$ exam participation in 4-year college enrollment. Educational Measurement: Issues and Practice, 30(4), 16-27. doi: 10.1111/j.17453992.2011.00219.x

College Board. (2005). Advanced Placement report to the Nation. Retrieved from https://secure-media.collegeboard.org/digitalServices/pdf/ap/rtn/ap-reportnation_2005.pdf

College Board. (2015). AP Biology, Workshop Handbook and Resources. New York: College Board.

Dods, R. F. (1997). An action research study of the effectiveness of problem-based learning in promoting the acquisition and retention of knowledge. Journal for the Education of the Gifted, 20(4), 423-437.

Fredricks, J. A., Blumenfeld, P.C., \& Paris, A.H. (2004). School engagement: Potential of the concept, state of the evidence. Review of Educational Research, 74(1), 59-109. https://doi.org/10.3102/00346543074001059.

Gormally, C., Brickman, P., Hallar, B., \& Armstrong, N. (2009) Effects of Inquiry-based Learning on Students' Science Literacy Skills and Confidence, International Journal 
for the Scholarship of Teaching and Learning, (3)2. Available at: https://doi.org/10.20429/ijsotl.2009.030216

Hallett, R. E., \& Venegas, K. M. (2011). Is Increased Access Enough? Advanced Placement Courses, Quality, and Success in Low-Income Urban Schools. Journal for the Education of the Gifted, 34(3), 468-487. https://doi.org/10.1177/016235321103400305

Heijne-Penninga, M., Kuks, J., Hofman, W., Muijtjens, A., Cohen-Schotanus, J. (2013). Influence of PBL with open-book tests on knowledge retention measured with progressive tests. Advances in Health Science Education, 18, 485-495. DOI $10.1007 / \mathrm{s} 10459-012-9386-8$

Hidi, S., \& Renninger, K. A. (2006). The Four-Phase Model of Interest Development. Educational Psychologist, 41(2), 111-127. doi: 10.1207/s15326985ep4102_4

Hmelo, C.E. (1998). Problem-based learning: Effects on the early acquisition of cognitive skill in medicine. Journal of Learning Science. 7(2), 173-208.

Hmelo-Silver, C. E., (2004). Problem-based learning: What and how do students learn? Educational Psychology Review, 16(3), 235-266.

Kim, J.K. (2005). The Effect of a Constructivist Teaching Approach on Student Academic Achievement, Self -concepts and learning strategies. Asia Pacific Education Review. 6(1), 7-19. Retrieved from https://files.eric.ed.gov/fulltext/EJ728823.pdf 
McPhail, G. (2016). The Fault Lines of Recontextualization: the limits of Constructivism in Education. British Educational Research Journal. (42)2, 294-313. DOI 10.1002/berj.3199.

Nayak, D. K. (2007). A study on the effect of constructivist pedagogy on students' achievement in mathematics at elementary level. National Institute of Open Schooling, MHRD, Noida. Retrieved from http://www.ncert.nic.in/pdf_files/Rajendra\%20Kumar\%20Nayak.pdf

Palmer, D. H. (2009). Student interest generated during an inquiry skills lesson. Journal of Research in Science Teaching, 46(2), 147-165. doi: 10.1002/tea.20263

Qarareh, A.O. (2016). The Effect of Using the Constructivist Learning Model in Teaching Science on The Achievement and Scientific Thinking of 8th Grade Students. International Education Studies. (30)7 Retrieved from https://files.eric.ed.gov/fulltext/EJ1106532.pdf

Rotgans, J., \& Schmidt, H. (2014). Situational interest and learning: Thirst for knowledge. Learning and Instruction, 32, 37-50. https://doi.org/10.1016/j.learninstruc.2014.01.002

Ruiz-Gallardo, J., Gonzalez-Geraldo, J., \& Castano, S. (2016). What are our students doing? Workload, time allocation and time management in PBL instruction. A Case study in Science Education. Teaching and Teacher Education. 53, 51-62. https://doi.org/10.1016/i.tate.2015.10.005

Sagge, S. (2016). Effect of Socio-Constructivist Approach of Teaching on Responsible Environmental Behavior in Relation to Intelligence. Scholarly Research Journal for Interdisciplinary Studies, 23(3), 1630-1639. 
Schmidt, H. G., Rotgans, J. I., \& Yew, E.H.J. (2011). The process of problem-based learning: what works and why. Medical Education, 45, 792-806.

Schraw, G., Flowerday, T., \& Lehman, S. (2001). Increasing Situational Interest in the Classroom. Educational Psychology Review, 13(3), 211-224.

Silander, P. (2015). Digital Pedagogy. In P. Mattila, \& P. Silander (Eds.), How to create the school of the future: Revolutionary thinking and design from Finland (pp. 9-26). Oulu: University of Oulu, Center for Internet Excellence. Retrieved from http://www.classter.com/wp-content/uploads/2016/09/How-to-create-the-school-ofthe-future.pdf

Sulaiman, F., Atan, H., Idrus, R., \& Dzakiria, H. (2004). Problem-Based Learning: A Study of the Web-Based Synchronous Collaboration. Malaysian Online Journal of Instructional Technology, 1 (2), 58-66. ISSN 1823-1144.

Symeonidis, V., \& Schwarz, J. F. (2016). Phenomenon-Based Teaching and Learning through the Pedagogical Lenses of Phenomenology: The Recent Curriculum Reform in Finland. Forum O`swiatowe, 28 (2), 31-47. Retrieved from http://forumoswiatowe.pl/index.php/czasopismo/article/view/458

Taraban, R., Box, C., Myers, R., Pollard, R., \& Bowen, C. (2007). Effects of ActiveLearning Experiences on Achievement, Attitudes, and Behaviors in High School Biology. Journal of Research in Science Teaching, 44(7), 960-979. doi: 10.1002/tea.20183

Thomas, G. (2017). How to do your research project: A guide for students. Los Angeles: SAGE. 


\section{Appendix A. Student Interest Survey}

For each of the units we studied, we looked at a problem, we had a discussion with the white-board and we had a lab investigation. Of these three, which did you find MOST interesting?
a. Overarching unit problem
b. Lab investigations
c. Discussions

Why was that aspect of the units the most interesting?

For each of the units we studied, we looked at a problem, we had a discussion with the white-board, and we had a lab investigation. Of these three, which did you find LEAST interesting?
a. Overarching unit problem
b. Lab investigations
c. Discussions

Why was that aspect of the unit the least interesting?

Did giving a problem at the start of each unit affect your interest in the course? Please explain. 